\title{
Development and Physicochemical, Sensory and Microbiological Characterization of Ferment Milk With Addition of Cupuaçu
}

\author{
Nélio Ranieli F. Paula ${ }^{1}$, Érica O. Araújo ${ }^{1}$, Emily E. Almeida ${ }^{1} \&$ Joene P. Cerqueira $^{1}$ \\ ${ }^{1}$ Federal Institute of Education, Science and Technology, Rodonia State, Campus Colorado, Brazil \\ Correspondence: Érica O. Araújo, Federal Institute of Education, Science and Technology, Rodonia State, \\ Campus Colorado, Brazil. Tel: 69-98126-0921. E-mail: erica.araujo@ifro.edu.br
}

Received: December 16, 2019

Accepted: February 2, $2020 \quad$ Online Published: April 15, 2020

doi:10.5539/jas.v12n5p122

URL: https://doi.org/10.5539/jas.v12n5p122

\begin{abstract}
The development of dairy products using probiotic microorganisms has been an important focus in the food industry. Thus, the present study aimed to evaluate the physicochemical, sensory and microbiological quality of fermented milk with addition of cupuaçu (Theobroma grandiflorum) flavor. The experimental design used was completely randomized, with five replicates, arranged in a $4 \times 2 \times 2$ factorial scheme, consisting of fermented milk with addition of four different strains of probiotic bacteria (Lactobacillus casei shirota, Lactobacillus casei, Lactobacillus acidophilus and Lactobacillus paracasei), presence and absence of cupuaçu flavor, and two evaluation times ( 1 and 7 days of storage). The results allowed us to conclude that the bacterial strain B (Lactobacillus casei) led to higher values of $\mathrm{L}^{*}, \mathrm{~b}^{*}, \% \mathrm{Brix}$ and $\mathrm{pH}$. In the presence of cupuaçu flavor, the values of $\mathrm{pH}, \mathrm{L}^{*}, \mathrm{~b}^{*}$ and \%Brix were significantly higher, which allows us to infer that cupuaçu pulp contributes to decreasing the values of $\mathrm{pH}$ and increasing the acidity, lightness, $\mathrm{b}^{*}$ and \%Brix of fermented milk. Fermented milk with addition of bacteria A (Lactobacillus casei shirota) in the presence of cupuaçu flavor showed reduction in $\mathrm{pH}$ and \%Brix and, therefore, better acceptance by consumers and bioconservation. The presence of cupuaçu flavor in fermented milk with bacteria B (Lactobacillus casei) alters $\mathrm{L}^{*}$ and $\mathrm{b}^{*}$ at seven days of storage. Fermented milk with addition of cupuaçu flavor constitutes an opportunity and possibility for developing new flavors from Amazonian fruits, strongly contributing to the durability of dairy products, since the physicochemical, sensory and microbiological characteristics are enhanced within the standards of food safety.
\end{abstract}

Keywords: amazonian fruits, probiotic bacteria, production, technology, Theobroma grandiflorum

\section{Introduction}

Milk is a food composed of a combination of nutrients that are fundamental for consumption, such as water, carbohydrates, lipids, proteins, minerals and vitamins, such as A and D (fat-soluble) and B and C (water-soluble), which together provide important elements to health (Silva et al., 2008). Habitual consumption of this food is recommended, especially to achieve the recommended daily intake of calcium, a nutrient that, among other functions, is fundamental for the formation and maintenance of the body's bone structure (Muniz et al., 2013). Due to its nutritional profile, milk has been investigated in studies addressing the importance of its intake in the different phases of life, as well as potential health benefits attributed to its consumption and the use of probiotic bacteria.

The development of dairy products using probiotic microorganisms has been an important focus in the food industry. Currently, the production of foods containing specific probiotic strains with appropriate concentrations of viable cells along the shelf life is a technological challenge. Bacteria belonging to the genus Lactobacillus, such as those of the group Lactobacillus casei, Lactobacillus paracasei and Lactobacillus acidophilus, are very often used as probiotic supplements for food, especially for fermented milk, since they have been isolated from all portions of the gastrointestinal tract of healthy humans. The beneficial influence of probiotics on human intestinal microbiota includes factors such as antagonistic effects, competition and immunological effects, resulting in increased resistance against pathogens (Saad, 2006). Thus, the use of probiotic bacterial cultures stimulates the multiplication of beneficial bacteria, to the detriment of the proliferation of potentially harmful bacteria, reinforcing the natural defense mechanisms of the host (Puupponen-Pimiã et al., 2002).

Fermented milks, according to the Technical Regulation of Identity and Quality of Fermented Milk (Brazil, 2007), are products with or without the addition of other food substances, obtained by coagulation and reduction 
of milk $\mathrm{pH}$, or reconstituted, with or without the addition of other dairy products, by lactic fermentation through the action of cultures of specific microorganisms, and these must be viable, active and abundant in the final product during its shelf life. Such fermentation is performed with one or more of the following cultures: Lactobacillus acidophilus, Lactobacillus casei, Bifidobacterium sp., Streptococus salivarius subsp. thermophilus and/or other lactic acid bacteria that, through their activity, contribute to determining the characteristics of the final product (Brazil, 2007). However, the production of fermented milk, such as fermented milk with addition of fruits, is a considerable alternative for dairy industries and can constitute a rational and logical form of different types of processing, with various flavors, being part of a promising market within the Brazilian scenario.

The Brazilian Amazon is rich in diversity of plants that are still little explored by most of the population and that can become a food alternative of high nutritional value and with alleged presence of nutraceutical compounds. Among the fruits of great importance for the Amazon region, cupuaçu (Theobroma grandiflorum) stands out as the most commercially exploited and is part of the group of tropical fruits with excellent commercial value. The pulp is the most consumed part of this fruit and, due to the characteristics of acidity, pectin content, active aroma, pleasant taste, high contents of volatile compounds and mineral salts (Martins, 2008), it is an important raw material for the processing industry. Data from the Food and Agriculture Organization (FAO) have shown that the worldwide marketing of fruit products has significantly grown in recent years. The use of fruit pulp in the formulations of dairy beverages offers some advantages, such as giving pleasant taste and contributing to improving the nutritional value of foods (Zulueta, 2007).

Several studies have been carried out in the different segments aimed at discovering new nutritional and functional sources, and the diversity of bioactive compounds in foods justifies the endless search for information on their physicochemical, physiological or functional and sensory properties. Thus, considering the potential of the Amazon region regarding the investment in food technology, the production of fermented milk with addition of Amazonian fruits creates the opportunity for discovering new horizons for products with different treatments and that meet both national and international consumers, through the creation and exploration of Amazonian products and species. In addition, research should be based on the fact that the strategic decisions to be made by the agents of the milk and dairy production chain depend on a deep understanding of consumer behavior, which has not yet been sufficiently investigated in the country.

In view of the above, the present study aimed to evaluate the physicochemical, sensory and microbiological quality of fermented milk with addition of cupuaçu (Theobroma grandiflorum) flavor.

\section{Methods}

The experiment was conducted at the premises of the Food Agroindustry of the Federal Institute of Education, Science and Technology of Rondônia, Colorado do Oeste Campus, in the municipality of Colorado do Oeste, RO, Brazil, at the geographic coordinates $13^{\circ} 06^{\prime} \mathrm{S}$ and $60^{\circ} 29^{\prime} \mathrm{W}$, and average altitude of 407 meters.

The experimental design used was completely randomized, with five replicates, arranged in a $4 \times 2 \times 2$ factorial scheme, consisting of fermented milk with addition of four different strains of probiotic bacteria (Lactobacillus casei shirota, Lactobacillus casei, Lactobacillus acidophilus and Lactobacillus paracasei), presence and absence of cupuaçu flavor, and two times of evaluation ( 1 and 7 days of storage), in a total of 80 experimental units.

The milk used in the test was produced in the Animal Science sector of the Federal Institute of Education, Science and Technology of Rondônia, Colorado do Oeste Campus, and provided for the Food Agroindustry. Initially, this milk was skimmed to have a final maximum fat content of $0.5 \mathrm{~g} / 100 \mathrm{~g}$, according to the Normative Instruction $\mathrm{n}^{\circ} 62$ of 2011, in slow pasteurization, raising the temperature to $65^{\circ} \mathrm{C}$ for thirty minutes, followed by cooling to the temperature of incubation of fermenting microorganisms $\left(37^{\circ} \mathrm{C}\right)$, in a rigorously controlled environment for a period of 7 hours. Milk fermentation occurred until the $\mathrm{pH}$ of the medium reached values of $4.0( \pm 0.25)$. This $\mathrm{pH}$ interval was determined considering the sensory and conservation characteristics of the product. The fermenting microorganisms used came from different commercial products and their samples were identified as treatments A, B, C and D, which correspond to: A (Lactobacillus casei shirota), B (Lactobacillus casei), $\mathrm{C}$ (Lactobacillus acidophilus) and D (Lactobacillus paracasei).

Fermented milk with and without cupuaçu flavor was produced by adding $9 \%$ sugar in each treatment. Subsequently, the milk was heated to prepare the syrup, and part of it received $5 \%$ of natural pulp of cupuaçu (Theobroma grandiflorum).

Treatments that, after processing, showed apparent viscosity visually similar to/compatible with that of fermented milk existing on the market were subjected to physicochemical analyses: $\mathrm{pH}$, acidity, colorimetric 
parameters $\mathrm{L}^{*}$ (lightness ranging from 0 [totally black] to 100 [totally white]), $\mathrm{a}^{*}\left(-80\right.$ green to +100 red) and $\mathrm{b}^{*}$ (intensity from -50 blue to +70 yellow), and \%Brix, analyzed at the first and seventh days of storage.

The sensory acceptance test (attributes: color, texture, consistency, aroma, taste, appearance and overall aspect) was performed at seven and fifteen days of storage, in triplicates. Sensory evaluation of acceptance was carried out by untrained tasters and considering the scores according to the hedonic scale with values from 1 to 9 points (1-disliked extremely, 2-disliked very much, 3-disliked moderately, 4-disliked slightly, 5-Neither liked nor disliked, 6-liked slightly, 7-liked moderately, 8-liked very much and 9-liked extremely), indicating how much they liked or disliked the color, texture, consistency, aroma, taste, appearance and overall aspect of the products. Purchase intention was evaluated by means of a mixed structured scale with 5 points (1-would buy, 2-possibly would buy; 3-maybe would buy, 4-possibly would not buy and 5-would not buy).

Microbiological determinations were performed according to the methodology described by Brazil (2003), evaluating the presence of total coliforms, Escherichia coli, Staphylococcus aureus, Salmonella sp., based on the microbiological parameters recommended by the legislation for fermented dairy beverages (Brazil, 2005).

The physicochemical, sensory and microbiological results were subjected to analysis of variance and the differences in the means were compared by Tukey test at 5\% significance level, using Sisvar software.

\section{Results and Discussion}

The results showed significant effects $(\mathrm{p} \leq 0.05)$ of the interaction between bacteria $(\mathrm{B})$ and flavor $(\mathrm{F})$ on $\mathrm{b}^{*}, \mathrm{pH}$ and \%Brix (Table 1), while the interaction between bacteria (B) and time (T) influenced only the colorimetric parameter $\mathrm{L}^{*}$ (Table 2), and the interaction between flavor (F) and time (T) only affected $\mathrm{L}^{*}$ and $\mathrm{b}^{*}$ (Table 3). There was no significant effect of the triple interaction of the factors on any of the physicochemical variables analyzed.

Further analysis of the double interaction between bacteria (B) and flavor (F) showed that the bacterial strain A was statistically superior to the probiotic bacteria $\mathrm{B}, \mathrm{C}$ and $\mathrm{D}$, both in the presence and absence of cupuaçu flavor for $\mathrm{pH}$ values (Table 1). In the presence of cupuaçu flavor, the bacterial strain A led to $\mathrm{pH}$ values on the order of 4.02 , statistically differing $(\mathrm{p} \leq 0.05)$ from the treatment without cupuaçu flavor $(\mathrm{pH}$ of 4.32$)$, which showed a $7.46 \%$ reduction in $\mathrm{pH}$ values in the presence of cupuaçu flavor and reduction in \%Brix (Table 1). This probably occurred because of the low $\mathrm{pH}$ and high acidity of cupuaçu pulp. For the same analysis, bacteria $\mathrm{D}$ led to the lowest values of $\mathrm{pH}(\mathrm{pH} 3.32)$ and, therefore, the highest values of acidity compared to the other bacteria (A, B and $\mathrm{C}$ ), as well as the highest values of \%Brix, both in the absence and presence of cupuaçu flavor (Table 1 ).

There was no statistical difference in $\mathrm{pH}$ values in the presence and absence of cupuaçu flavor for the treatment with bacteria $\mathrm{D}$; the $\mathrm{pH}$ values remained stable, around 3.32, both in the absence and presence of cupuaçu flavor. In addition, there was no statistical difference in \%Brix. Such higher acidity caused by bacteria D is related to the metabolites produced by these lactic acid bacteria, which contribute to inhibiting the growth of microorganisms. It is known that, at the beginning of fermentation, milk $\mathrm{pH}$ favors the development of Streptococcus salivarius subspecies thermophilus, which tends to be inhibited when $\mathrm{pH}$ reaches values from 4.2 to 4.4. However, the increase in acidification, that is, in lactic acid content, favors the growth of Lactobacillus delbrueckii subspecies bulgaricus, which can tolerate $\mathrm{pH}$ values within the range from 3.5 to 3.8 (Andrade, 2010). From the obtained data, it can be inferred that the $\mathrm{pH}$ values observed in the treatments meet the minimum value established for fermented milk recommended by the Technical Regulation of Identity and Quality (RTIQ) of Fermented Milks (Brazil, 2007).

The colorimetric parameter $\mathrm{L}^{*}$ was higher in fermented milk with bacteria B in the presence of cupuaçu flavor, differing statistically from the other bacteria and in the absence of cupuaçu flavor. This means that the addition of bacteria B in milk fermentation promoted greater lightness in the product (Table 1), corroborating the data of the colorimetric variable $b^{*}$, which pointed to a slightly yellowish color in the fermented milk, as shown in Table 2. 
Table 1. Colorimetric parameter $\mathrm{L}^{*}, \mathrm{pH}$ and $\%$ Brix of fermented milk with different strains of probiotic bacteria in the absence and presence of cupuaçu flavor

\begin{tabular}{llc}
\hline \multirow{2}{*}{ Bacteria } & \multicolumn{2}{c}{ Flavor } \\
\cline { 2 - 3 } Colorimetric $L^{*}$ & Absence & Presence \\
A & $40.14 \mathrm{aB}$ & $58.66 \mathrm{bA}$ \\
$\mathrm{B}$ & $43.21 \mathrm{aB}$ & $60.56 \mathrm{aA}$ \\
$\mathrm{C}$ & $36.44 \mathrm{aB}$ & $57.11 \mathrm{bA}$ \\
$\mathrm{D}$ & $40.99 \mathrm{aB}$ & $57.27 \mathrm{bA}$ \\
\hline$p H$ & & \\
A & $4.32 \mathrm{aA}$ & $4.02 \mathrm{aB}$ \\
B & $3.44 \mathrm{cB}$ & $3.52 \mathrm{cA}$ \\
C & $3.85 \mathrm{bA}$ & $3.86 \mathrm{bA}$ \\
$\mathrm{D}$ & $3.32 \mathrm{dA}$ & $3.32 \mathrm{dA}$ \\
\hline$\%$ Brix & & \\
A & $14.77 \mathrm{cA}$ & $14.82 \mathrm{bA}$ \\
B & $15.00 \mathrm{bcA}$ & $15.15 \mathrm{aA}$ \\
C & $15.22 \mathrm{abA}$ & $14.65 \mathrm{bB}$ \\
D & $15.27 \mathrm{aA}$ & $15.12 \mathrm{aA}$ \\
\hline
\end{tabular}

Note. Lowercase letters separate the means within each column, and the capitals separate the means within the row. Equal letters do not differ from each other by the tukey test at $5 \%$ probability.

There were significant effects of the different strains of probiotic bacteria at both times of storage of fermented milk on the colorimetric variables $\mathrm{L}^{*}$ and $\mathrm{b}^{*}$. At seven days of storage, the bacteria B led to the highest values of $\mathrm{L}^{*}$ and $\mathrm{b}^{*}$, compared to the other probiotic bacteria, and differed statistically $(\mathrm{p} \leq 0.05)$ when compared to the first storage time (Table 2). At the first storage time, bacteria A differed significantly from the others, promoting the highest values of $L^{*}$ and lowest values of $b^{*}$ (Table 2).

Table 2. Colorimetric parameters $\mathrm{L}^{*}$ and $\mathrm{b}^{*}$ of fermented milk with different strains of probiotic bacteria on the first and seventh days of storage

\begin{tabular}{lll}
\hline Bacteria & $1^{\circ}$ Day & $7^{\circ}$ Day \\
\hline Colorimetric $L^{*}$ & & \\
$\mathrm{~A}$ & $44.59 \mathrm{aB}$ & $56.21 \mathrm{bA}$ \\
$\mathrm{B}$ & $33.80 \mathrm{bB}$ & $65.97 \mathrm{aA}$ \\
$\mathrm{C}$ & $37.26 \mathrm{bB}$ & $56.29 \mathrm{bA}$ \\
$\mathrm{D}$ & $30.83 \mathrm{bB}$ & $57.41 \mathrm{bA}$ \\
\hline Colorimetric $b^{*}$ & $9.12 \mathrm{bB}$ & $12.12 \mathrm{bA}$ \\
$\mathrm{A}$ & $12.13 \mathrm{aB}$ & $14.65 \mathrm{aA}$ \\
$\mathrm{B}$ & $8.65 \mathrm{bB}$ & $12.22 \mathrm{bA}$ \\
$\mathrm{C}$ & $10.17 \mathrm{abB}$ & $11.86 \mathrm{bA}$ \\
$\mathrm{D}$ & & \\
\hline
\end{tabular}

Note. Lowercase letters separate the means within each column, and the capitals separate the means within the row. Equal letters do not differ from each other by the tukey test at $5 \%$ probability.

Table 3. Colorimetric parameters $\mathrm{L}^{*}$ and $\mathrm{b}^{*}$ of fermented milk in the absence and presence of cupuaçu flavor on the first and seventh days of storage

\begin{tabular}{lll}
\hline Sabor & $1^{\circ}$ Day & $7^{\circ}$ Day \\
\hline Colorimetric $L^{*}$ & & \\
Absence & $20.23 \mathrm{bB}$ & $57.78 \mathrm{aA}$ \\
Presence & $53.00 \mathrm{aB}$ & $60.15 \mathrm{aA}$ \\
\hline Colorimetric $b^{*}$ & & \\
Absence & $7.36 \mathrm{bB}$ & $12.14 \mathrm{aA}$ \\
Presence & $13.28 \mathrm{aA}$ & $12.65 \mathrm{aA}$ \\
\hline
\end{tabular}

Note. Lowercase letters separate the means within each column, and the capitals separate the means within the row. Equal letters do not differ from each other by the tukey test at $5 \%$ probability. 
The other results did not show significant effect of the interaction and are presented independently for each factor (Figures 1 and 2). For the independent effect of the studied factors, there was significant difference ( $p \leq$ 0.05 ) between the different strains of probiotic bacteria for the variables $\mathrm{L}^{*}, \mathrm{a}^{*}, \mathrm{~b}^{*}, \mathrm{pH}$ and \%Brix. Compared to the strains A, C and D, the bacteria B led to significantly higher values of $\mathrm{L}^{*}, \mathrm{~b}^{*}$ and \%Brix (Figures $1 \mathrm{~A}, 1 \mathrm{~B}$ and 1C), lower values of $\mathrm{pH}$ and consequently higher acidity (Figure 2B). These data reveal good lightness, yellowish color and slight sweetness of the fermented milk with addition of probiotic bacteria $\mathrm{B}$. In the presence of cupuaçu flavor and at seven days of storage, there were statistical differences $(p \leq 0.05)$ for $L^{*}, b^{*}$ and $\% B r i x$ when compared to treatments in the absence of cupuaçu flavor and at the first day of storage (Figures $1 \mathrm{~A}, 1 \mathrm{~B}$ and 1C). The percentage increments in relation to the absence and presence of cupuaçu flavor corresponded to $37.82 \%, 4.21 \%$ and $26.97 \%$, respectively, for $\mathrm{L}^{*}, \mathrm{~b}^{*}$ and $\%$ Brix, while the increments corresponding to the storage time were $61 \%, 20.15 \%$ and $4.88 \%$ for the same variables mentioned above. The $\mathrm{pH}$ value in the absence of cupuaçu flavor was higher than that of the treatment in the presence of cupuaçu flavor, which allows us to infer that cupuaçu pulp contributed to decreasing the values of $\mathrm{pH}$ and increasing the acidity of fermented milk (Figure 2B).

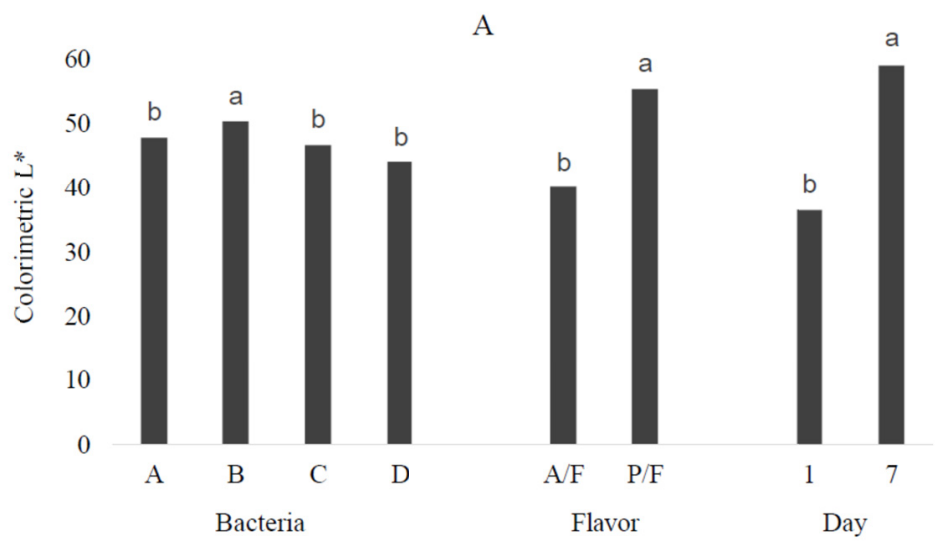

B

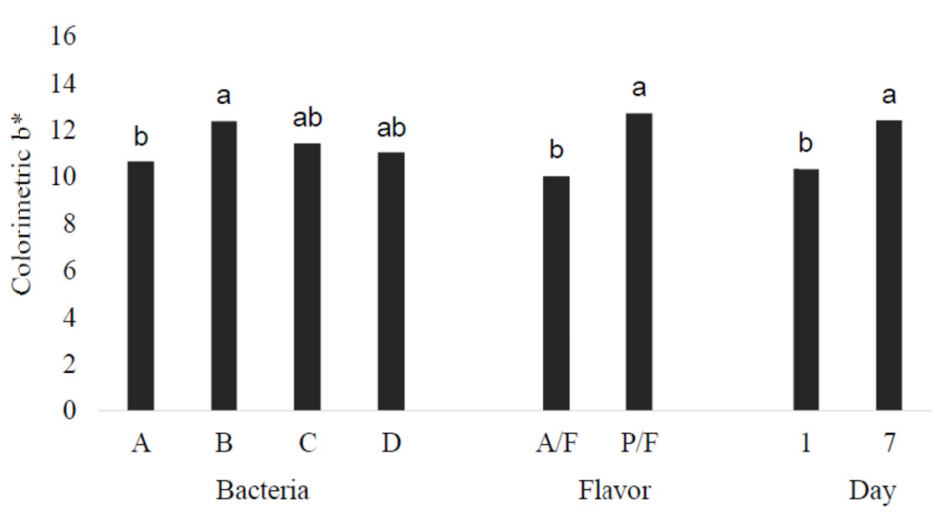




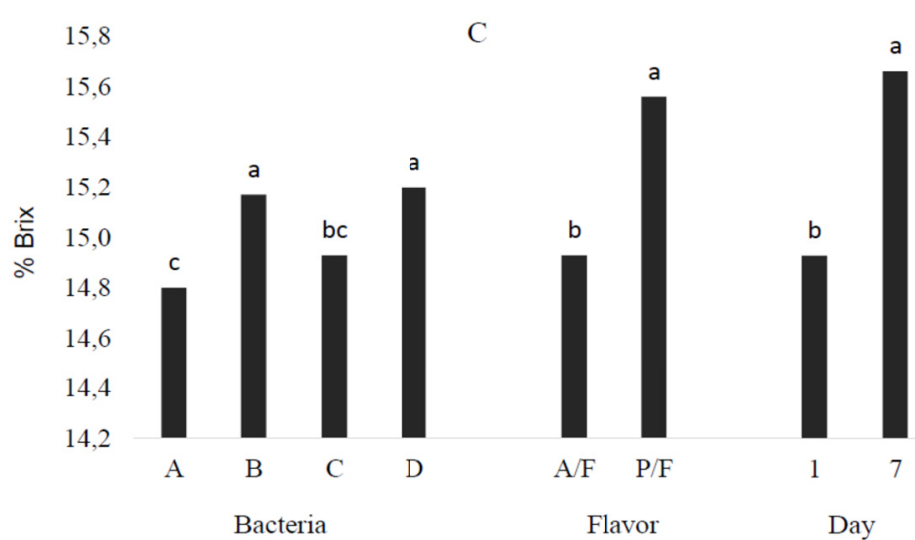

Figure 1. Colorimetric parameters $L^{*}(A)$ and $b^{*}(B)$ and $\%$ Brix $(C)$ of fermented milk with different strains of probiotic bacteria, in the absence and presence of cupuaçu flavor and at different storage times. Means followed by the same letter on the bars do not differ statistically by Tukey test at $5 \%$ probability level

5
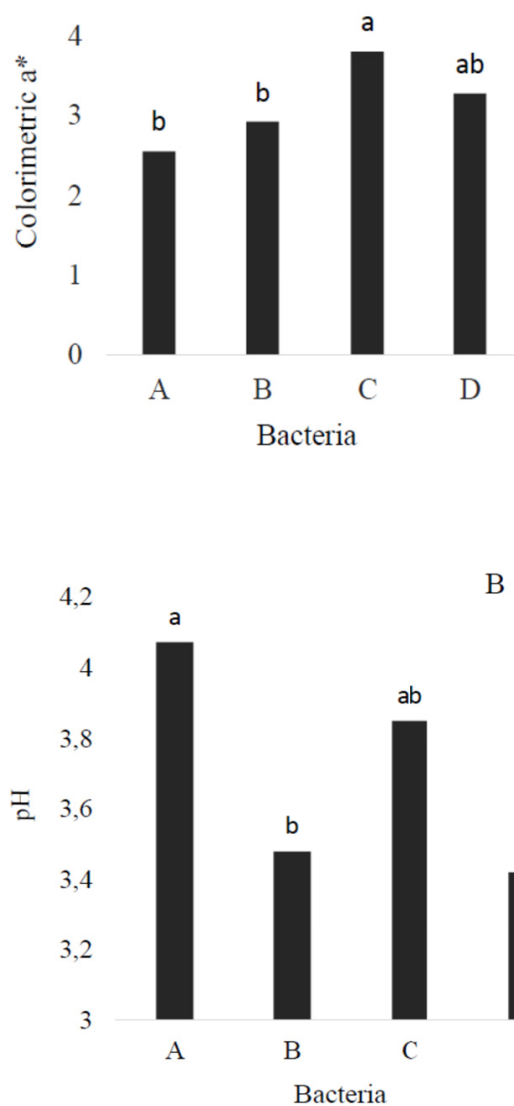

A

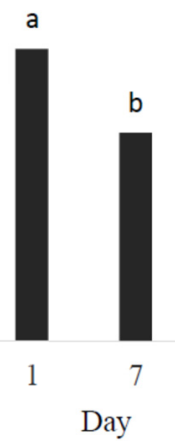

$\mathrm{B}$

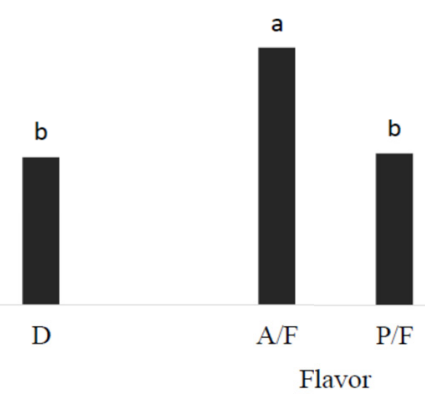

Figure 2. Colorimetric parameter $\mathrm{a}^{*}(\mathrm{~A})$ and $\mathrm{pH}(\mathrm{B})$ of fermented milk with different strains of probiotic bacteria and at different storage times and in the absence and presence of cupuaçu flavor. Means followed by the same letter on the bars do not differ statistically by Tukey test at $5 \%$ probability level

Regarding sensory variables, there were no significant effects $(p \geq 0.05)$ of the interaction between bacteria (B) and flavor $(F)$, and the independent results for each factor, when significant $(p \leq 0.05)$, are presented in Table 4 and Figure 3. 
The most accepted treatments with the different probiotic bacteria in terms of the attributes of color, aroma, appearance and overall aspect, considering the values of the means closest to the descriptive terms "liked slightly" and "liked moderately", were those promoted by the addition of bacteria A, which led to the highest values of acceptance for all attributes mentioned above and did not differ statistically from the bacteria $\mathrm{C}$ and $\mathrm{D}$, indicating that these products have good acceptance and can be marketed. According to Dutcosky (2011), a product reaching a percentage equal to or greater than $70 \%$ is considered accepted by the tasters. For the same analysis, the use of bacteria $\mathrm{B}$ resulted in the lowest values of acceptance, averaging around 5.42 , so it fits in the acceptance class "Neither liked nor disliked" (Table 4).

It is relevant to mention that bacteria A promoted the best results in the analysis of bacteria $(\mathrm{B}) \times$ flavor $(\mathrm{F})$ interactions for the physicochemical evaluations of $\mathrm{L}^{*}, \mathrm{pH}$ and \%Brix, and that the results corroborate those found in the acceptance test (Figures 3A and 3B).

Table 4. Sensory analysis of fermented milk in the absence and presence of cupuaçu flavor

\begin{tabular}{lllll}
\hline Bacteria & Color & Odor & Appearance & Aspect \\
\hline A & $7.35 \mathrm{a}$ & $7.20 \mathrm{a}$ & $7.00 \mathrm{a}$ & $7.17 \mathrm{a}$ \\
$\mathrm{B}$ & $5.25 \mathrm{~b}$ & $5.57 \mathrm{~b}$ & $5.87 \mathrm{~b}$ & $5.02 \mathrm{~b}$ \\
$\mathrm{C}$ & $6.80 \mathrm{ab}$ & $6.25 \mathrm{ab}$ & $6.97 \mathrm{ab}$ & $7.32 \mathrm{a}$ \\
$\mathrm{D}$ & $6.67 \mathrm{ab}$ & $6.40 \mathrm{ab}$ & $6.45 \mathrm{ab}$ & $6.57 \mathrm{ab}$ \\
\hline
\end{tabular}

Lowercase letters separate the averages within each column. Equal letters do not differ from each other by the Tukey test at $5 \%$ probability. $\mathrm{n}=80$ judges. 1 Structured hedonic scale of nine points $(1=\mathrm{i}$ greatly disliked; $9=\mathrm{i}$ really liked it). The values correspond to the mean with estimate of the standard deviation.

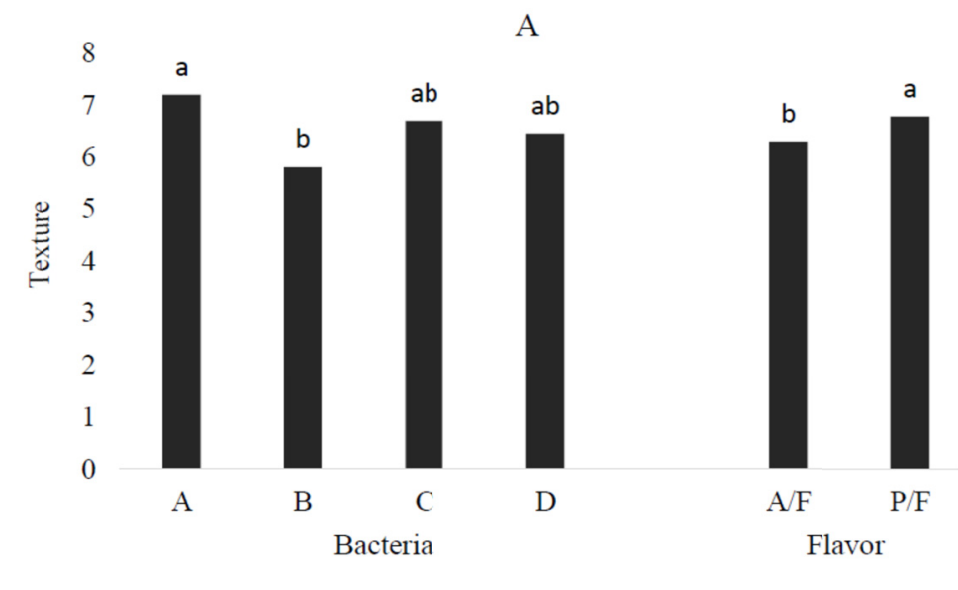

A

B

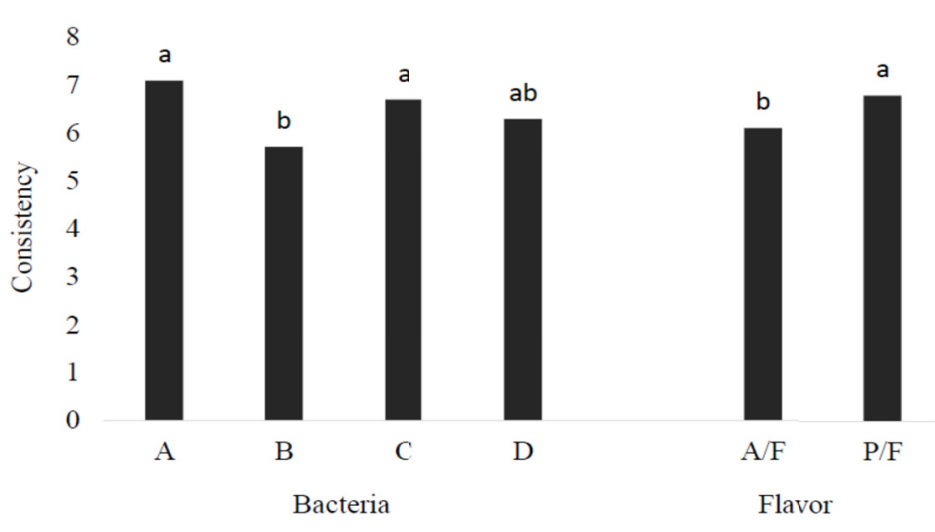

Figure 3. Texture (A) and consistency (B) of fermented milk with different strains of probiotic bacteria, in the presence and absence of cupuaçu flavor. Means followed by the same letter on the bars do not differ statistically by Tukey test at $5 \%$ probability level 
In all samples of fermented milk, the Most Probable Number $/ \mathrm{mL}(\mathrm{MPN} / \mathrm{mL})$ of coliforms at $35^{\circ} \mathrm{C}$ and coliforms at $45^{\circ} \mathrm{C}$ were lower than $0.3 \mathrm{MPN} / \mathrm{mL}$. According to the RTIQ of Fermented Milk (Brazil, 2005), the MPN/mL of coliforms allowed for fermented dairy beverages is up to $100 \mathrm{MPN} / \mathrm{mL}$ of coliforms at $35^{\circ} \mathrm{C}$ and $10 \mathrm{MPN} / \mathrm{mL}$ of coliforms at $45^{\circ} \mathrm{C}$ for indicative samples. The results indicate adequate hygienic-sanitary quality throughout the process of production and storage of the fermented beverages and demonstrate microbiological quality above the level required by the current legislation, therefore suitable for consumption (Table 5). According to the Brazilian legislation, Salmonella spp. must be completely absent (Brazil, 2001). The shelf life of fermented milk was longer than 60 days, with maintenance of quality of the sensory characteristics of the product.

Table 5. Microbiological analysis of fermented milk in the absence and presence of cupuaçu flavor

\begin{tabular}{llllll}
\hline Bacteria & Total C. & Thermotolerant & E. coli & S. aureus & Salmonella sp. \\
\hline Absence cupuaçu & & & & & \\
A & 0.1 & 0.1 & Absence & Absence & Absence \\
B & 0.1 & 0.1 & Absence & Absence & Absence \\
C & 0.1 & 0.1 & Absence & Absence & Absence \\
D & 0.1 & 0.1 & Absence & Absence & Absence \\
Presence cupuaçu & & & & Absence \\
A & 0.3 & 0.1 & Absence & Absence & Absence \\
B & 0.3 & 0.1 & Absence & Absence & Absence \\
C & 0.3 & 0.1 & Absence & Absence & Absence \\
D & 0.3 & 0.1 & Absence & Absence & .
\end{tabular}

Note. The values correspond to the average of three replicates. *Reference standards according to the Normative Instruction $\mathrm{n}^{\mathrm{o}} 16$ of 08/23/2005 of the Ministry of Livestock, Agriculture and Food Supply. Total C. (Total coliforms), E. coli (Escherichia coli), S. aureus (Staphylococcus aureus).

\section{Conclusions}

A bactéria $\mathrm{B}$ (Lactobacillus casei) apresentou-se valores de colorimetria $\mathrm{L}^{*}$, colorimetria $\mathrm{b}^{*}, \%$ Brix and $\mathrm{pH}$ superiore Bacteria $\mathrm{B}$ (Lactobacillus casei) led to higher values of $\mathrm{L}^{*}, \mathrm{~b}^{*}, \% \mathrm{Brix}$ and $\mathrm{pH}$.

In the presence of cupuaçu flavor, the values of $\mathrm{pH}, \mathrm{L}^{*}, \mathrm{~b}^{*}$ and $\%$ Brix were significantly higher, which allows us to infer that cupuaçu pulp contributes to decreasing the values of $\mathrm{pH}$ and increasing the acidity, lightness, $\mathrm{b}^{*}$ and $\%$ Brix of fermented milk.

Fermented milk with addition of bacteria A (Lactobacillus casei shirota) in the presence of cupuaçu flavor showed reduction in $\mathrm{pH}$ and $\%$ Brix values and, therefore, better acceptance by consumers and bioconservation.

The presence of cupuaçu flavor in fermented milk with bacteria B (Lactobacillus casei) alters the colorimetric parameters $\mathrm{L}^{*}$ and $\mathrm{b}^{*}$ at seven days of storage.

The microbiological quality was higher than that required by the current legislation, indicating adequate hygienic-sanitary quality throughout the process of production and storage of the fermented beverages.

Fermented milk with addition of cupuaçu flavor constitutes an opportunity and possibility for developing new flavors from Amazonian fruits, strongly contributing to the durability of dairy products, since the physicochemical, sensory and microbiological characteristics are enhanced within the standards of food safety.

\section{References}

Andrade, E. H. P. (2010). Physicochemical, microbiological quality and detection of whey by high efficiency liquid chromatography in fermented dairy beverages (68f., Dissertation (Master's degree in Animal Science), Federal University of Minas Gerais, MG).

Brazil, Ministry of Agriculture, Livestock and Supply. (2003). Secretariat of Animal Product Inspection. Normative Instruction No. 62 of August 26, 2003 (Section 1, p. 14). It formalizes official analytical methods for microbiological analysis for the control of products of animal origin and water. Official Gazette [of] Federative Republic of Brazil, Brasília, DF. 
Brazil, Ministry of Agriculture, Livestock and Supply. (2005). Secretariat of Animal Product Inspection. Normative Instruction No. 16 of August 23, 2005 (Section 1, p. 7). Approves the Technical Regulation of Identity and Quality of Milky Beverages. Official Gazette [of] Federative Republic of Brazil, Brasília, DF.

Brazil, Ministry of Agriculture, Livestock and Supply. (2007). Secretariat of Animal Product Inspection. Normative Instruction No. 46 of October 23, 2007 (Section 1, p. 5). It adopts the Technical Regulation of Identity and Quality of Fermented Milks. Official Gazette [of] Federative Republic of Brazil, Brasília, DF.

Dutcosky, S. D. (2011). Sensory analysis of food (3rd ed., p. 426). Curitiba: Editora Champagnat.

Martins, V. B. (2008). Sensory profile of tropical cupuaçu juice (Theobroma grandiflorum Schum) (p. 366, Thesis (Doctorate in Food and Nutrition), State University of Campinas, SP).

Muniz, L. C., Madruga, S. W., \& Araújo, C. L. (2013). Consumption of milk and dairy products among adults and the elderly in southern Brazil: A population-based study. Collective Health Science, 18(12), 3515-3522. https://doi.org/10.1590/S1413-81232013001200008

Puupponen-Pimiã, R., Aura, A. M., Oksmancaldentey, K. M., Myllarinen, P., Saarela, M., Mattila-Sanholm, T., \& Poutanen, K. (2002). Development of functional ingredients for gut health. Trends Food Sci. Technol., 13(1), 3-11. https://doi.org/10.1016/S0924-2244(02)00020-1

Saad, S. M. I. (2006). Probiotics and prebiotics: State of the art. Brazilian Journal of Pharmaceutical Sciences, 42(1), 1-16. https://doi.org/10.1590/S1516-93322006000100002

Silva, M. C., Ramos, A. C. S., Melo, R. O., \& Oliveira, J. O. (2008). Microbiological and physicochemical characterization of pasteurized milk destined to the milk program in the State of Alagoas. Food Science and Technology, 28(1), 226-230. https://doi.org/10.1590/S0101-20612008000100032.

Zulueta, A., Frasquet, I., Esteves, M. J., \& Frígola, A. (2007). Vitamin C, vitamin A, phenolic compounds and antioxidante capacity of new fruit juice and skim milk mixture beverages marketed in Spain. Food Chemistry, 103(4), 1365-1374. https://10.1016/j.foodchem.2006.10.052

\section{Copyrights}

Copyright for this article is retained by the author(s), with first publication rights granted to the journal.

This is an open-access article distributed under the terms and conditions of the Creative Commons Attribution license (http://creativecommons.org/licenses/by/4.0/). 